\title{
高温高圧水素の粘性係数推算式の提案 \\ Prediction of Hydrogen Gas Viscosity at High Pressure and High Temperature
}

\author{
Elin Yusibani*, Peter L. Woodfield**, 新里寛英**, 河野正道*, \\ 高田保之*，藤井丕夫** \\ Elin YUSIBANI", Peter L.WOODFIELD ${ }^{* *}$, Kanei SHINZATO ${ }^{* *}$, M. KOHNO*, \\ Yasuyuki TAKATA*, Motoo FUJII**
}

\begin{abstract}
本報では高温高圧状態の水素の粘性係数を簡便かつ正確に求めるための実用的な推算式を提案し た。従来，低密度気体に適用できる Chapman-Enskog 理論をベースにした式に，高密度補正を 加える方法が提案されているが，本推算式は，低密度領域で Chapman-Enskog 式における分子 間力定数を，高密度領域で Diller の密度補正式の定数を最適化することにより得られている．既 存の実測值と比較した結果，本推算式は高温・高圧力下の水素の粘性係数を偏差 $2 \sim 4 \%$ 以内で予 測出来ることが確かめられた。本推算式の適用範囲は, 圧力 $0.1 \mathrm{MPa}$ で温度範囲 $40 \sim 2130 \mathrm{~K}$, お よび 0.1〜220MPa で, 100〜990Kである.

キーワード:粘性係数, 高圧水素ガス, Chapman-Enskog 理論, 推算式
\end{abstract}

Accurate knowledge of hydrogen gas viscosity is extremely important for developing a hydrogen economy. There is a need for recommendations relating to the best available viscosity data and the best available correlations for practical purposes. The purpose of this work is to analyze the various possibilities for viscosity correlation to estimate hydrogen gas viscosity in the high pressure and high temperature region for practical industrial uses. We recommend suitable force constants and a collision integral for the Chapman-Enskog solution to estimate viscosity in the limit of zero density. At high density, modification of Diller's extrapolation equation for excess viscosity gives good agreement with the available experimental data. A combination of the Chapman-Enskog solution and modification of Diller's excess viscosity gives an estimation of hydrogen gas viscosity within 2 to $4 \%$ deviation from the existing experimental data for the high-temperature and high-pressure region.

[Keywords: Chapman-Enskog, correlation, gas, high pressure, high temperature, hydrogen, viscosity]

\section{Introduction}

Recently, interest in hydrogen gas has been increasing rapidly because of its potential to contribute towards resolving issues related to energy resourcing, energy security, global warming, and sustainable energy generation. One of the generation-IV reactors nuclear projects (HTGRs, HTR, VHTR) is designed to be coupled with a hydrogen producing power plant to produce pure hydrogen at high temperature in the process [1]. Presently, hydrogen is industrially produced from hydrocarbons such as methane and is used widely in ammonia production. However, it is preferable to produce hydrogen from water using the

\footnotetext{
* $\quad 744$ Motooka Nishi-ku Fukuoka $\bar{T}$ 819-0395 Department of Mechanical Engineering, Kyushu University,

** $\quad 744$ Motooka Nishi-ku Fukuoka 819-0395

Research Center for Hydrogen Industrial Use and Storage (HYDROGENIUS), National Institute of Advanced Industrial Science and Technology (AIST) Corresponding author: Elin Yusibani

E-mail: e-yusibani@aist.go.jp
}

process of electrolysis where the electricity is from renewable sources. Hydrogen is an environmentally clean energy carrier for the user, and is particularly attractive for transportation applications because the release of pollutants is very low at the point of end use. Hydrogen is the most abundant of the chemical elements and accurate knowledge of the thermophysical properties of hydrogen gas is extremely important for developing a hydrogen society. The viscosity of hydrogen is very important and it is a basic property required for developing any device in which hydrogen gas flows. The purpose of this work is to analyze the various possibilities for viscosity correlation (semi-theoretical or empirical) to estimate hydrogen gas viscosity in the high temperature and high pressure region and then a recommendation for the most suitable correlation is proposed.

\section{Existing Experimental Data}

There are several experimental techniques available to obtain hydrogen gas viscosity data. Table 1 shows the selected experimental data used to compare with 
the present correlation. We selected only the published data sets which include high temperature and high pressure because we want to make a correlation particularly in this region. Unfortunately, the existing wide-range correlations at high temperature and high pressure have accuracies poorer than $5 \%$. The temperatures are from 40 to $2128 \mathrm{~K}$ and the pressures are from 0.0009 to $217 \mathrm{MPa}$. The highest pressure data was collected by Rudenko et al. [2]. The highest temperature data was collected by Guevara et al. [3]. The most recent data was collected by May et al. [4] (213 to $394 \mathrm{~K}, 0.1 \mathrm{MPa}$ ).

\section{Existing Correlations}

\subsection{Low-Density Region}

To estimate hydrogen gas viscosity, we need information about two regions of density i.e., the low density region and the high density region. At atmospheric pressure, hydrogen gas viscosity may be considered to be at the limit of zero density, $\eta_{\mathrm{o}}(T)$, which can be well represented by the Chapman-Enskog solution as a first approximation [5].

$$
\eta_{\mathrm{o}}(T)=\frac{5}{16} \frac{\sqrt{\pi m k T}}{\pi \sigma^{2} \Omega_{\eta}\left(T^{*}\right)}
$$

where, $m$ is the mass of one hydrogen molecule $\left(m=M / N_{\text {avo }}=2.01594 \times 10^{-3} / 6.022 \times 10^{23} \mathrm{~kg}\right)$ and $T$ is the temperature. This relation requires three parameters, i.e., collision diameter, $\sigma$, and collision integral, $\Omega_{\eta}$, as a function of reduced temperature, $T^{*}=T /(\varepsilon / k)$. $\varepsilon$ is a maximum energy of attraction and $k$ is the Boltzmann constant $\left(k=1.3806504 \times 10^{-23} \mathrm{~J} \cdot \mathrm{K}^{-1}\right)$. Table 2 shows various force constants and collision integrals for hydrogen gas. Reported values range in Table 2 is from $\sigma=0.2695$ to $0.3337 \mathrm{~nm}$ and $\varepsilon / k=29.2$ to $79.4 \mathrm{~K}$. This range of values is the result of using different collision integrals and different data sets for hydrogen viscosity. Besides the Chapman-Enskog solution, other empirical correlations at low-density for hydrogen gas viscosity are also studied. We tabulated the correlations for the low-density region in Table 3.

\subsection{High-Density Region}

Correlations for hydrogen gas viscosity applied to high density are not sufficiently accurate at present. Therefore, we are interested in developing a new correlation for practical use. For industrial purposes, it is desirable to obtain a simple correlation with a high accuracy. To estimate hydrogen gas viscosity at high-density, the common approach is to add an extra term $\Delta \eta(T, \rho)$, known as the excess viscosity, to correct for the effect of the gas density as given in Eq. (2).

$$
\eta(T, \rho)=\eta_{\mathrm{o}}(T)+\Delta \eta(T, \rho)
$$

For some gases, experimental data has been correlated successfully assuming that the excess viscosity is a function of the density only (e.g. [6]). For lighter molecules such as hydrogen, however the temperature dependence of the excess viscosity is important. Diller [7] and McCarty et al. [8] use a temperature dependent excess viscosity relation of the form given in Eq. (3) for estimation hydrogen gas viscosity at high density.

$$
\Delta \eta(T, \rho)=A(\rho) \exp [B(\rho) / T]
$$

Diller mentioned in his paper that the assumption of the excess viscosity being independent of temperature is not adequate especially at densities greater than twice of the critical point value where the temperature dependence is much greater. However, Diller and McCarty correlations are limited to the low temperature region and the pressure up to $35 \mathrm{MPa}$.

As another alternative to the excess viscosity relation, the density dependence of viscosity can also be estimated using Enskog theory (Eq.4).

$$
\eta(T, \rho)=b \rho \eta_{\mathrm{o}}(T)[1 /(b \rho \chi)+0.800+0.7614 b \rho \chi]
$$

$b$ and $\chi$ can be derived either empirically or theoretically. Michels et al. [9] and Hanley et al. [10] compare Enskog theory with the experimental hydrogen data. Because Enskog theory is not valid in extreme density regions, Hanley modified the Enskog theory and named it Modified Enskog Theory (MET). However, Michels and Hanley correlations show deviations from the experimental data around $10 \%$ at high density. We tabulated the correlations for the high-density region in Table 4.

\section{New Correlation}

\subsection{Low-Density Region}

At low-density we use the Chapman-Enskog solution. The Chapman-Enskog solution is a very simple equation as shown by Eq.1. However, the applicability of the solution strongly depends on the selected parameters for the collision integral and intermolecular force constants. The collision integral, $\Omega_{\eta}$, empirically developed by Assael et al. [11] for the hydrogen gas case was used in the present correlation, Eq. 5. Assael used his primary data selected to evaluate the function $\Omega_{\eta}$, over the temperature $20-2200 \mathrm{~K}$ at pressure $0.1 \mathrm{MPa}$. The force constants $\sigma=0.2968 \mathrm{~nm}$ and $\varepsilon / \kappa=33.3 \mathrm{~K}$ were chosen. These force constants were derived from hydrogen viscosity experiments and classical formulae which are useful for rough calculations [5]. For the present correlation, we recommend a combination of force constants of 0.296 $\mathrm{nm}$ and $35 \mathrm{~K}$. These force constants were chosen to fit with the existing available data set in Table 1.

$$
\begin{aligned}
& \Omega_{\eta}\left(T^{*}\right)=\exp \left(0.354125-0.427581\left(\ln T^{*}\right)\right. \\
& +0.149251\left(\ln T^{*}\right)^{2}-0.037174(\ln T)^{3} \\
& \left.+0.003176\left(\ln T^{*}\right)^{4}\right)
\end{aligned}
$$




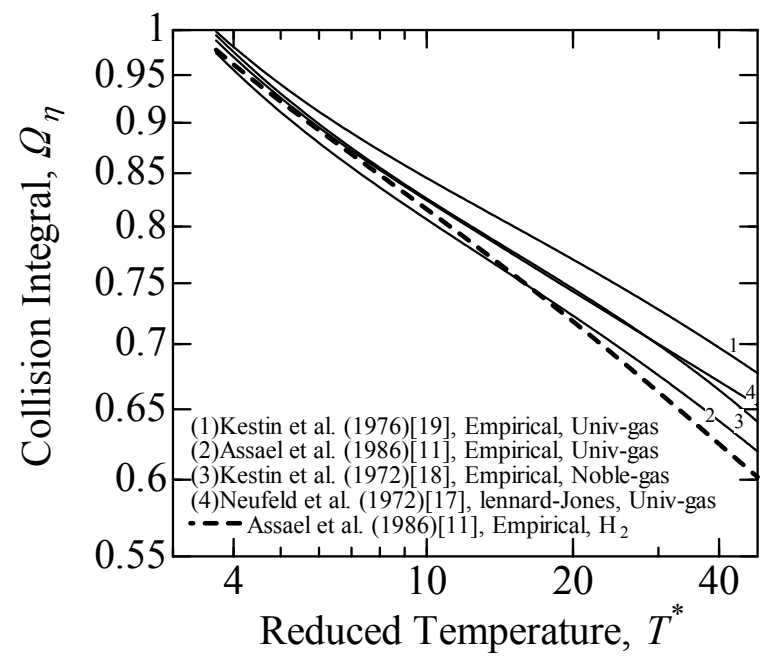

Fig. 1 Collision integral versus reduced temperature

In the present analysis, hydrogen gas density was calculated from an equation of state derived by Leachman [16]. To determine $\Omega_{\eta}$ for the case of hydrogen, the Lennard-Jones potential is commonly used as an intermolecular potential energy function. However, the Lennard-Jones potential is an approximation [5]. Therefore, in the present correlation we use a collision integral developed by Assael et al. based directly on hydrogen viscosity data. Figure 1 shows the comparison of the collision integral for hydrogen and other gases versus reduced temperature.

For the Lennard-Jones potential, the collision integral data is conveniently available as an empirical equation developed by Neufeld et al. [17]. The hydrogen collision integral developed by Assael has a different trend to the other curves in that the rate of decrease with respect to the reduced temperature is faster at larger values of $T^{*}$. The collision integral for hydrogen is lower than the universal gas collision integrals, especially at high temperature. The other

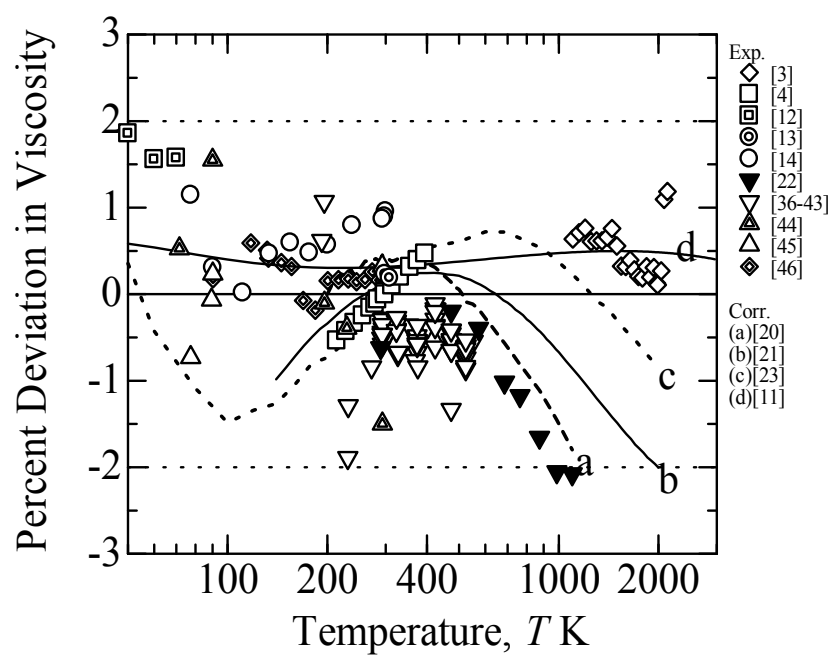

Fig. 2 Hydrogen viscosity deviation vs temperature at low density. (a, b, c, d, correspond to correlations in Table 3) collision integrals deviate from Assael's by as much as $13 \%$ for $T^{*}>30[18,19]$.

Figure 2 shows the percent deviation in viscosity of dilute gas correlations tabulated in Table 3 from the present correlation. Mason et al. [20], Hanley et al. [21], Assael et al. and the present correlation used the Chapman-Enskog solution as a base equation at low-density. In spite of the different force constants, collision integral and experiment data selected, the discrepancy between these correlations and the present correlation is as much as $1 \%$ (for $\mathrm{c}$ and $\mathrm{d}$ ) and up to $2 \%$ (for a and b). Assael's correlation gives a better agreement with the data of Guevara et al. [3] than the present correlation. However, it deviates more than $2 \%$ from the data of Trautz et al. [22] around $1000 \mathrm{~K}$. Figure 2 shows that the force constants used in the present correlation give a better agreement in average with the existing experimental data than those used by Assael. Standard deviation of the existing data set in Fig. 2 from the present correlation is as much as 0.10 $\mu \mathrm{Pas}$ and a little larger deviation $0.11 \mu \mathrm{Pas}$ is obtained from Assael's correlation. Maitland's correlation [23] is a pure empirical relation for prediction of hydrogen viscosity at low-density. It also agrees with the present correlation within $1 \%$.

\subsection{High-Density Region}

At high density, we use an excess viscosity relation Eq. 3 rather than Enskog theory Eq. 4. The present excess viscosity expression is modification of the Diller's expression shown in Table 4 by changing the constant values in $A(\rho)$ and $B(\rho)$ as

$$
\begin{gathered}
A(\rho)=\exp \left(5.73+\ln (\rho)+65.0 \rho^{3 / 2}-\right. \\
\left.6.00 \times 10^{-6} \exp (135 \rho)\right) \\
B(\rho)=T_{\mathrm{o}}\left\{10.0+8\left[\left(\frac{\rho}{0.07}\right)^{6}-\left(\frac{\rho}{0.07}\right)^{\frac{3}{2}}\right]-18 \exp \left[-59\left(\frac{\rho}{0.07}\right)^{3}\right]\right\}
\end{gathered}
$$

Figure 3 shows the effect of pressure on hydrogen gas viscosity at $25^{\circ} \mathrm{C}$ for existing correlations and the present correlation. This isotherm was selected since there are a number of experimental data by various authors at high pressure. The viscosity correlation derived by Diller is slightly higher than the experimental data at high pressure. However, the good agreement with the experimental data is surprising since Diller's expression was developed for data at low temperature below $100 \mathrm{~K}$. Therefore we conclude that we still can use Diller's expression for excess viscosity with a slight modification in the higher temperature and higher density region. The applicable ranges of temperature and pressure of the present correlation are 40 to $2130 \mathrm{~K}$ for dilute gas and 100 to $990 \mathrm{~K}$ for 0.1 to $220 \mathrm{MPa}$, respectively. The present correlation, as can be seen in the Fig.3, gives a good agreement with respect to the existing experimental data. The Enskog theory of Michels's with parameters $\chi$ and $b$, 


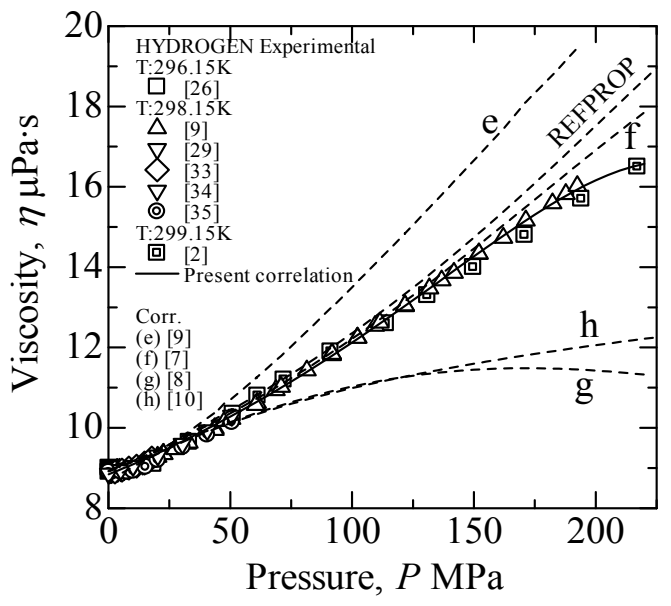

Fig.3 Viscosity comparison at $25 \mathrm{oC}(\mathrm{e}, \mathrm{f}, \mathrm{g}$, and $\mathrm{h}$ correspond to the correlations in Table 4)

REFPROP [24] and Diller's correlation give reasonably good agreement with the present correlation up to $30 \mathrm{MPa}$. The Modified Enskog Theory (MET) derived by Hanley's and McCarty's correlation give lower estimations for viscosity at high density above $50 \mathrm{MPa}$.

Figure 4 shows a comparison of the present excess viscosity correlations with respect to Diller's and McCarty's correlations. At low density they give a good agreement up to $23 \mathrm{~kg} \cdot \mathrm{m}^{-3}$. As for McCarty's correlation, increasing rate becomes low at $23 \mathrm{~kg} \cdot \mathrm{m}^{-3}$ and it reaches a maximum at around $65 \mathrm{~kg} \cdot \mathrm{m}^{-3}$. On the other hand, Diller's correlation increases more steeply than the present at higher densities.

Figure 5 shows the percent deviation in hydrogen viscosity experimental versus pressure. Diller's correlation (Table 4, f) at $100 \mathrm{MPa}$ gives a larger discrepancy at high temperature region. Figure 6 shows the percent deviation in hydrogen viscosity experimental versus temperature. Tsederberg et al. measured (Ref. [23]) hydrogen gas at around $900 \mathrm{~K}$ at $50 \mathrm{MPa}$. He estimated the accuracy of his data set is $3 \%$. Totally, the discrepancy of the present correlation with respect to the existing hydrogen gas viscosity experiment data at high pressure and high temperature agree within 2 to $4 \%$ (Figs.5 and 6).

\section{Conclusion}

A new correlation has been derived to estimate hydrogen gas viscosity at high pressure and high temperature. The correlation is very simple and convenient for practical use. It is based on the Chapman-Enskog solution and the excess viscosity relation. The discrepancy of the present correlation is as much as 2 to $4 \%$ with published data selected from the high-temperature and high-pressure region. Temperature and pressure ranges of the present correlation are 40 to $2130 \mathrm{~K}$ for dilute gas, and 100 to $990 \mathrm{~K}$ for 0.1 to $220 \mathrm{MPa}$, respectively.

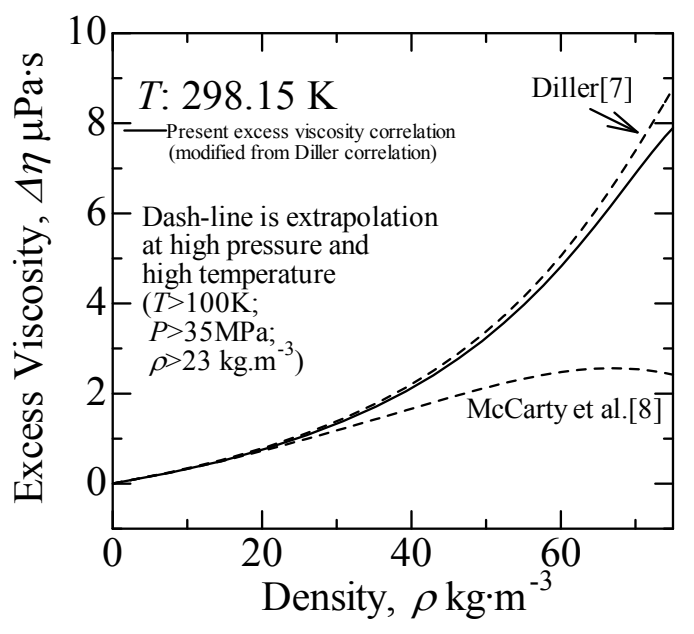

Fig.4 Excess viscosity simulation (Eq. (3)

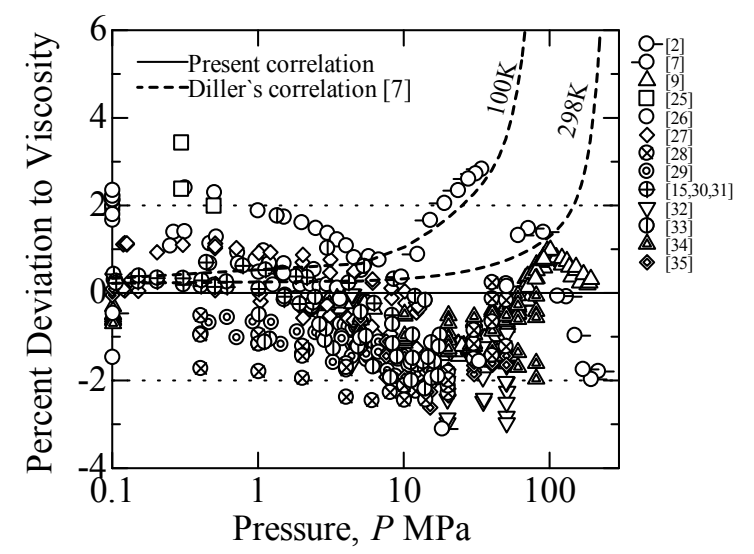

Fig. 5 Viscosity deviation vs. pressure

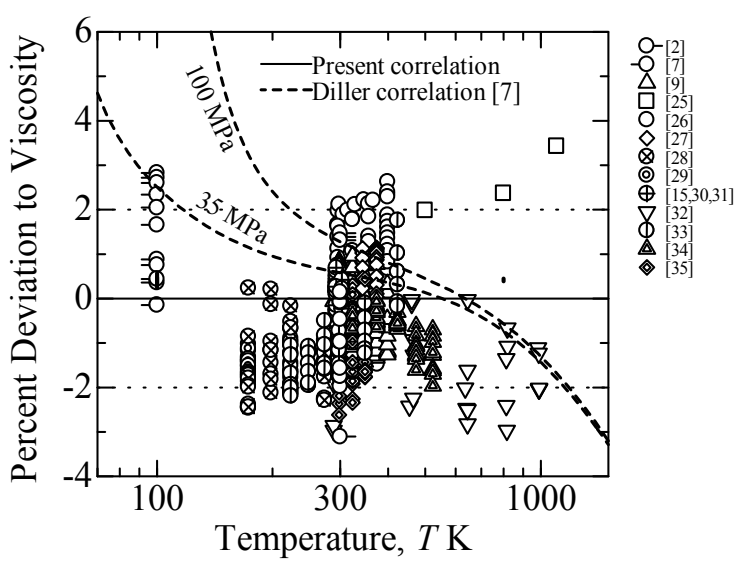

Fig.6 Viscosity deviation vs. pressure

\section{ACKNOWLEDGEMENT}

This research has been conducted as a part of the "Fundamental Research Project on Advanced Hydrogen Science" funded by the New Energy and Industrial Technology Development Organization (NEDO). 
Table 1 Selected Experimental Data Set

\begin{tabular}{|c|c|c|c|c|c|c|c|}
\hline References & $\begin{array}{c}\text { Uncer- } \\
\text { tainty,\% }\end{array}$ & $T / \mathrm{K}$ & $P / \mathrm{MPa}$ & References & $\begin{array}{l}\text { Uncer- } \\
\text { tainty,\% }\end{array}$ & $T / \mathrm{K}$ & $P / \mathrm{MPa}$ \\
\hline May et al. & 0.08 & $213.62-394.21$ & 0.1 & Kestin et al.*[30,31] & $0.05-0.2$ & $293.15-303.15$ & $0.1-2.3$ \\
\hline Maltsev et al.[25] & 3 & $500,800,1100$ & $0.1-1$ & Rudenko et al. & $4-6$ & 300 & $0.1-217$ \\
\hline Nabizadeh et al.[26] & $0.5-1$ & $295.55-399.15$ & $0.1-5.8$ & Tsederberg et al.[32] & 3 & $288.65-989.65$ & $4.4-50.92$ \\
\hline Clifford et al.* & 0.2 & $198.15-208.15$ & 0.1 & Barua et al. *[33] & 0.2 & $223.15-423.15$ & $1.01-20.26$ \\
\hline Hongo et al. [27] & 0.3 & $298.15-373.15$ & $0.1-12.5$ & Golubev et al.[34] & ns & $288.15-523.15$ & $0.1-81.04$ \\
\hline Chuang et al. [28] & 0.5 & $173.15-273.15$ & $0.4-50.6$ & Michels et al.* & ns & $298.15-398.15$ & $2.1-192.4$ \\
\hline Guevara et al.* & 0.4 & $1102-2128$ & 0.1 & Kuss [35] & 2 & $298.15-348.15$ & $0.1-50.66$ \\
\hline Gracki et al. * [29] & $0.1-0.2$ & $173.15-298.15$ & $15.2-25.3$ & Trautz et al.*[36-43] & ns & $195.15-1098$ & 0.1 \\
\hline Menabde et al. * & 2 & $77-299$ & 0.1 & Rietveld et al.*[44] & ns & $71-293$ & $0.0009-0.005$ \\
\hline Coreman et al. $*$ & $2-3$ & $40-80$ & 0.1 & Itterbeek\&Paemel *[45] & ns & $77-293$ & 0.1 \\
\hline Diller & 0.5 & 100 & $0.6-34.5$ & Johnston\&McCloskey [46] & $<0.3$ & $90-300$ & 0.1 \\
\hline
\end{tabular}

Table 2 Force Constants for Hydrogen Gas

\begin{tabular}{|c|c|c|c|c|c|c|c|}
\hline \multirow{2}{*}{ References } & \multicolumn{2}{|c|}{ Force Constants } & \multirow{2}{*}{$\Omega_{\eta}$} & \multirow{2}{*}{ References } & \multicolumn{2}{|c|}{ Force Constants } & \multirow{2}{*}{$\Omega_{\eta}$} \\
\hline & $\sigma / \mathrm{nm}$ & $\varepsilon / k / \mathrm{K}$ & & & $\sigma / \mathrm{nm}$ & $\varepsilon / k / \mathrm{K}$ & \\
\hline Nabizadeh et al. & 0.2695 & 79.4 & Empirical[19] & Kestin \& Nagashima & 0.2892 & 46.2 & L-J \\
\hline Hanley et al. & 0.2970 & 39.2 & L-J [47] & Hirschfelder et al. & 0.2968 & 33.3 & L-J (Cl) \\
\hline Hirschfelder et al. & 0.2915 & 38.0 & L-J $(\mathrm{Cl})$ & De Boer[50] & 0.2928 & 37.0 & L-J (Qu) \\
\hline Hirschfelder et al. & 0.2870 & 29.2 & L-J (Cl) & Mason and Rice & 0.3287 & 37.0 & L-J [51] \\
\hline Michels et al. [48] & 0.2958 & 36.7 & L-J (Qu)[49] & Mason and Rice & 0.3337 & 37.3 & Exp-Six [52] \\
\hline \multicolumn{8}{|c|}{ L-J:Lennard-Jones potential; Cl:Classical formulae; Qu:Quantum formulae } \\
\hline
\end{tabular}

Table 3 Correlations at Low Density

\begin{tabular}{|c|c|c|c|}
\hline No & References & Equations/method & Experiments \\
\hline $\mathrm{a}$ & $\begin{array}{l}\text { Mason and } \\
\text { Rice } \\
\text { n-hydrogen }\end{array}$ & $\begin{array}{l}\eta_{o}(T)=\frac{266.93 f_{\eta}}{\sigma^{2}} \frac{\sqrt{M T}}{\Omega_{\eta y}} ; \sigma=0.3337 \mathrm{~nm} ; \varepsilon / k=37.3 \mathrm{~K} \\
M \text { is molecular weight; } f_{\eta} \text { and } \Omega_{\eta} \text { is dimensionless and tabulated in } \\
\text { his paper; } \Omega_{\eta} \text { calculated by the Exp- } 6 \text { potential developed by } \\
\text { Mason } \\
T_{\text {range }}=200-1098 \mathrm{~K}\end{array}$ & $\begin{array}{l}\text { Johnston \& McCloskey; } \\
\text { Trautz et al.;Wobser \& } \\
\text { Muller [53] }\end{array}$ \\
\hline $\mathrm{b}$ & $\begin{array}{l}\text { Hanley et al. } \\
\text { p-Hydrogen } \\
\text { and } \\
\text { n-Hydrogen }\end{array}$ & $\begin{array}{l}\eta(T)=\eta_{o}\left\{1+3 / 196\left[8 \frac{\Omega^{(2,3)}}{\Omega_{\eta}}-7\right]^{2}\right\} \\
\eta_{o}(T)=\frac{5}{16} \frac{\sqrt{\pi m k T}}{\pi \sigma^{2} \Omega_{\eta}} ;\left(T_{\text {low }}\right) \sigma=0.297 \mathrm{~nm} ; \varepsilon / k=39.2 \mathrm{~K} ;\left(T_{\text {high }}\right) \sigma=0.306 \\
\mathrm{~nm} ; \varepsilon / k=30.4 \mathrm{~K} ; \Omega_{\eta} \text { calculated by the } 9-6 \text { potential; } \\
\mathrm{T}_{\text {range }}=15-5000 \mathrm{~K}\end{array}$ & $\begin{array}{l}\text { Guevara et al.; Barua et } \\
\text { al.; Van Itterbeek et al.; } \\
\text { Johnston \& McCloskey; } \\
\text { Wobser \& Muller; } \\
\text { Rietveld et al.; Kestin et } \\
\text { al.; Gracki et al.; } \\
\text { Sutherland \& Maass [54] }\end{array}$ \\
\hline $\mathrm{c}$ & $\begin{array}{l}\text { Maitland et al. } \\
\text { n-Hydrogen }\end{array}$ & $\begin{array}{l}\ln \left(\eta_{o} / 88.0[\mu P]\right)=0.68720 \ln T-0.61732 / T-111.49 / T^{2}-3.9001 \\
\mathrm{~T}_{\text {range }}=20-2200 \mathrm{~K}\end{array}$ & $\begin{array}{l}\text { Johnston \& McCloskey; } \\
\text { Kestin \& Leidenfrost; } \\
\text { Gracki et al.; Guevara et } \\
\text { al.; Barua et al.; Coreman } \\
\text { et al.; } \\
\text { Yen [55] }\end{array}$ \\
\hline d & $\begin{array}{l}\text { Assael et al. } \\
\text { n-Hydrogen }\end{array}$ & $\begin{array}{l}\eta_{o}(T)=\frac{5}{16} \frac{\sqrt{\pi m k T}}{\pi \sigma^{2} \Omega_{\eta}\left(T^{*}\right)} \\
\sigma=0.2968 \mathrm{~nm} ; \varepsilon / k=33.3 \mathrm{~K} ; \Omega_{\eta} \text { calculated empirically from } \\
\text { hydrogen viscosity experiment; } T_{\text {range }}=20-2200 \mathrm{~K}\end{array}$ & $\begin{array}{l}\text { Asterisk }(*) \text { symbol in } \\
\text { Table } 1\end{array}$ \\
\hline
\end{tabular}


Table 4 Correlations at High Density and the Present Recommended Correlation

\begin{tabular}{|c|c|c|c|}
\hline No & References & Equations/method & Experiments \\
\hline $\mathrm{e}$ & Michels et al. & $\begin{array}{l}\text { Enskog-theory } \\
\eta(T, \rho)=\eta_{\mathrm{o}}(T) b \rho[1 / b \rho \chi+0.800+0.7614 b \rho \chi] \\
\eta_{\mathrm{o}}=\eta(\text { at } 0.1 \mathrm{MPa}) ; \quad b=2 \pi \sigma^{3} / 3 m \\
m \text { is mass of hydrogen; } b \rho \chi \text { is calculated from the PVT data }\end{array}$ & $\begin{array}{l}\text { Michels et al. } \\
\text { Ranges: } \\
\text { T:298-398K } \\
\text { P:0.1-200 MPa }\end{array}$ \\
\hline $\mathrm{f}$ & Diller & $\begin{array}{l}\text { Excess viscosity relation } \\
\eta(T, \rho)=\eta_{\mathrm{o}}(T)+\Delta \eta(T, \rho) \\
\eta_{\mathrm{o}}=8.5558\left[T^{3 / 2} / T+19.55\right][(T+650.39) /(T+1175.9)] \times 10^{-6} \\
\Delta \eta(T, \rho)=A(\rho) \exp [B(\rho) / T] \\
A(\rho)=\exp \left\{5.7694+\log _{\mathrm{e}}(\rho)+65.0 \rho^{3 / 2}-6.00 \times 10^{-6} \exp (127.2 \rho)\right\} \\
B(\rho)=T_{\mathrm{o}}\left\{10.0+7.2\left[\left(\frac{\rho}{0.07}\right)^{6}-\left(\frac{\rho}{0.07}\right)^{\frac{3}{2}}\right]-17.63 \exp \left[-58.75\left(\frac{\rho}{0.07}\right)^{3}\right]\right\} \\
\text { note that } T_{\mathrm{o}}=1.0 \mathrm{~K} \text { and } \rho \text { is in } \mathrm{g} \cdot \mathrm{cm}^{-3} .\end{array}$ & $\begin{array}{l}\text { Diller } \\
\text { Ranges: } \\
\text { T:14-100 K } \\
\text { P:0.1-35 Mpa }\end{array}$ \\
\hline $\mathrm{g}$ & Mc-Carty et al. & $\begin{array}{l}\text { Excess viscosity relation } \\
A(\rho)=\frac{\left(306.4636 \rho-3350.628 \rho^{2}+3868.092 \rho^{3}\right)}{\left(1.0-18.47830 \rho+110.915 \rho^{2}+25.3524 \rho^{3}\right)} \times 10^{-6} \\
B(\rho)=10.0+7.2\left[\left(\frac{\rho}{0.07}\right)^{6}-\left(\frac{\rho}{0.07}\right)^{\frac{3}{2}}\right]-17.63 \exp \left[-58.75\left(\frac{\rho}{0.07}\right)^{3}\right] \\
\begin{array}{l}\text { McCarty modified Diller`s correlation on excess viscosity at high } \\
\text { density. }\end{array}\end{array}$ & $\begin{array}{l}\text { Diller } \\
\text { Ranges: } \\
\mathrm{T}<100 \mathrm{~K} \\
\mathrm{P}: 0.1-35 \mathrm{Mpa}\end{array}$ \\
\hline $\mathrm{h}$ & Hanley et al. & $\begin{array}{l}\text { Modified Enskog Theory (MET) } \\
\quad \eta(T, \rho)=\eta_{\mathrm{o}}(T)+\eta_{1} \rho+\ldots \\
\eta_{o}(T)=\frac{5}{16} \frac{\sqrt{\pi m k T}}{\pi \sigma^{2} \Omega_{\mu}\left(T^{*}\right)} ; \quad \eta_{1}=(-0.601( \pm 0.008)+0.8) b \eta_{\mathrm{o}} \\
b=2 \pi \sigma^{3} / 3 m ; \sigma=0.2970 \mathrm{~nm} ; \varepsilon / k=39.2 \mathrm{~K} ; \Omega_{\eta} \text { calculated by the } \\
\text { Lennard-Jones potential derived by Munn et al. }\end{array}$ & $\begin{array}{l}\text { Diller; Barua et al.; } \\
\text { Michels et al. } \\
\text { Ranges: } \\
\text { T>100 K }\end{array}$ \\
\hline $\mathrm{i}$ & $\begin{array}{l}\text { Present } \\
\text { correlation }\end{array}$ & 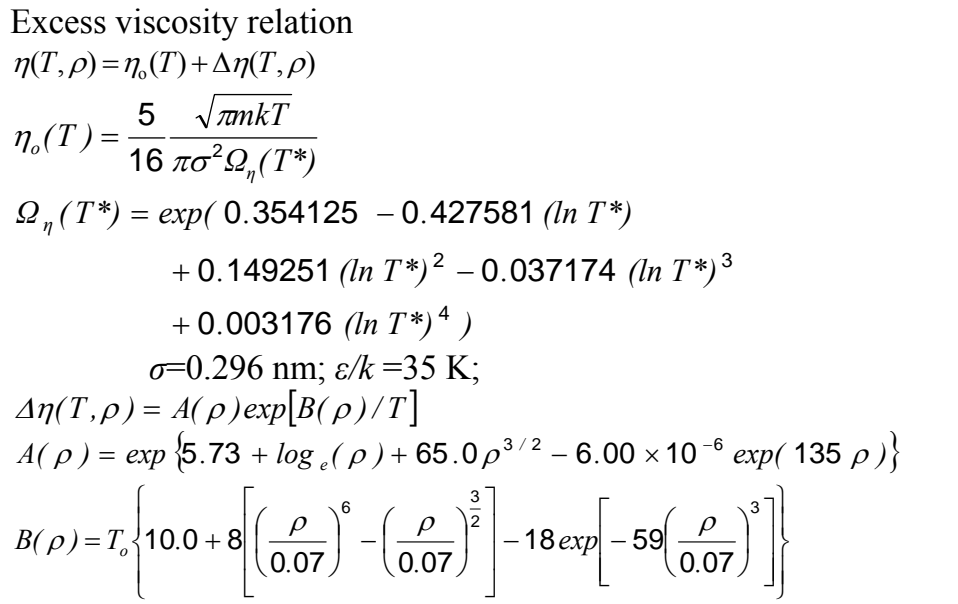 & $\begin{array}{l}\text { Table } 1 \\
\text { Ranges: } \\
\text { T: } 40 \text { to } 2130 \mathrm{~K} \\
\text { for dilute gas } \\
\text { and } \\
\text { T: } 100 \text { to } 990 \mathrm{~K} \\
\text { for } 0.1 \text { to } 220 \mathrm{Mpa}\end{array}$ \\
\hline
\end{tabular}

\section{REFERENCES}

[1] K. Onuki Y. Inagaki, R. Hino and Y. Tachibana, Prog. Nuc. En., 47 (2005) 496

[2] N. S. Rudenko and V. P. Slyusar, Ukr. Phys. Journal, 13 (1968) 656

[3] F. A. Guevara, B. B. McInteer, and W. E. Wageman, Phys. Fluids, 12 (1969) 2493

[4] E. F. May, R. F. Berg, and M. R. Moldover, In. J of Thermophys., 28 (4) (2007) 1085

[5] J. O. Hirschfelder, C. F. Curtis and R. B .Bird, Molecular Theory of Gases and Liquids, John Wiley \& Sons (1954)
[6] K. Stephan, R. Krauss, A. Laesecke, J. Phys. Chem. Ref. Data, 16 (4) (1987) 993

[7] D. E. Diller, J. Chem. Phys., 42 (1965) 6

[8] R. D. McCarty and L. A. Weber, Nat. Bur. Stand, Tech Note, 617 (1972) 16

[9] A. Michels, A. C. J. Schipper, and W. H. Rintoul, Physica (Amsterdam), 19 (1953) 1011

[10] M. J. M. Hanley, R. D. McCarty and E. G. D. Cohen, Physica, 60 (1972) 322

[11] M. J. Assael, S. Mixafendi and W. A. Wakeham, J. Phys. Chem. Ref. Data, 15 (1986) 4 
[12] M. J. Coreman, A. Van Itterbeek, J. J. M. Beenakker, H. F. P. Knaap and P. Zandbergen, Physica, 24 (1958) 557

[13] A. A. Clifford, J. Kestin and W. A. Wakeham, Ber. Bunsenges. Phys. Chem., 85 (1981) 385

[14] N. E. Menabde, Tranc. From Atonoya Energiya, 19 (1965) 5 (Sov. J. At. En, 19 (1965) 1421

[15] J. Kestin and A. Nagashima, Phys. Fluids, 7(5) (1964) 730;

[16] J. W. Leachman, M. Sc. Thesis, Brown University (2006)

[17] P. D. Neufeld, A. R. Janzen and R. A. Aziz, J. Chem. Phys, 57 (1972) 1100

[18] J. Kestin, S. T. Ro, and W. A. Wakeham, Physica, 58 (1972) 165

[19] J. Kestin, H. E. Khalifa, and W. A. Wakeham, J. Chem. Phys., 65 (12) (1976) 5186

[20] E. A. Mason and W. E. Rice, J. Chem. Phys., 22 (3) (1954) 522

[21] H. J. M. Hanley, R. D. McCarty and H. Intemann, J. Res. Nat. Bur. Standards A. Phys. Chem., 74A (3) (1970) 331

[22] V. M. Trautz and R. Zink, Annalen der physic, 399 (4) (1930) 427

[23] G. C. Maitland and E. B. Smith, J. Chem. Eng. Data, 17 (1972) 150

[24] REFPROP ver.8.0 - Reference Fluid thermodynamic and transport Properties developed by NIST -

[25] V. A. Mal'tsev, O. A. Nerushev, S. A. Novopashin, V. V. Rachenko, V. V. Licht, W. E. Miller and V. V. Perekh, J. Chem. Eng. Data, 49 (2004) 684.

[26] H. Nabizadeh and F. Mayinger, High Temp. High Pres., 31 (1999) 601

[27] M. Hongo and H. Iwasaki, The Rev. of Phys. Chem. of Japan, 48 (1) (1978) 1

[28] S.Y. Chuang, P. S. Chappelear, and R. Kobayashi, J. Chem. Eng. Data, 21 (1976) 403

[29] J. A. Gracki, G. P. Flynn, and J. Ross, J. Chem. Phys., 51(1969)3856

[30] J. Kestin and W. Leidenfrost, Physica, 25 (1959) 1033 ;

[31] J. Kestin and J. Yata, J. Chem. Phys., 49 (1968) 4780

[32] N. V. Tsederberg, V. N. Popov, I. I. Andreev, Teploenergetika, 12 (4) (1965) 84
[33] A. K. Barua, M. Afzal, G. P. Flynn and J. Ross, J. Chem. Phys., 41 (1964) 374

[34] I. F. Golubev and V. A. Petrov, Trudy GIAP, No. 2(1953)5 (as given in I. F. Golubev, Viscosity of Gases and Gas Mixtures. A Handbook Israel Program Sci. Transl. (1970)

[35] E. Kuss, Z. Angew. Phys., 4 (1952) 203

[36] V. M. Trautz and F. W. Stauf, Annalen der physic, 394 (6) (1929) 737

[37] V. M. Trautz and K. G. Sorg, Annalen der physic, 402 (1) (1931) 81

[38] V. M. Trautz and A. Melster, Annalen der physic, 399 (4) (1930) 409

[39] V. M. Trautz and W. Ludewigs, Annalen der physic, 395 (3) (1929) 409

[40] V. M. Trautz and F. Kurz, Annalen der physic,401 (8) (1931) 981

[41] V. M. Trautz and R. Heberling, Annalen der physic, 402 (2) (1931) 155

[42] V. M. Trautz and H. E. Binkele, Annalen der physic, 397 (5) (1930) 561

[43] V. M. Trautz and P. B. Baumann, Annalen der physic, 394 (6) (1929) 733

[44] A. O. Rietveld and A. V. Itterbeek, Physica, 23 (1957) 838

[45] A. Van Itterbeek, O. Van Paemel, Physica (Amsterdam) 7 (1940) 265

[46] H. L. Johnston and K. E. McCloskey, J. Phys. Chem. 44 (1940) 1038

[47] R. J. Munn, F. J. Smith, E. A. Mason and L. Monchick, J. Chem. Phys., 42 (1965) 537

[48] A. Michels, W. De Graaff, C. A. Seldam, Physica, 26 (1960) 393

[49] J. De Boer and A. Michels, Physica, 5 (1938) 10

[50] J. De Boer, Rep. on Progr. In Phys., 12 (1949) 305

[51] R. J. Lunbeck, Phd dissertation, Amsterdam (1951)

[52] E. A. Mason, The J. of Chem. Phys., 22 (2) (1954) 169

[53] R. Wobser and F. Muller, Kolloid-Beih 52 (1941) 165

[54] B. P. Sutherland and O. Maass, Can. J. Res. 6 (1932) 428

[55] K. Yen, Phil. Mag., 38 (1919) 582

[Received Oct. 20, 2009, Accepted Jan. 21, 2010] 